\title{
SERANGGA PREDATOR DAN PARASITOID DI DAERAH ENDEMIK SERANGAN ULAT API PADA PERKEBUNAN KELAPA SAWIT RAKYAT
}

\author{
Insect Predators and Parasitoids in Areas Endemic to Nettle Caterpillar Attacks \\ on Oil Palm Smallholder Plantations
}

\author{
Ahmad Firas Hakiki ${ }^{1}$, Yaherwandi ${ }^{2}$, dan Siska Efendi ${ }^{1 *}$ \\ ${ }^{1}$ Program Studi Agroekoteknologi, Fakultas Pertanian, Universitas Andalas \\ ${ }^{2}$ Program Studi Proteksi Tanaman, Jurusan Hama dan Penyakit Tumbuhan, \\ Fakultas Pertanian, Universitas Andalas
}

Alamat Korespondensi: (siskaefendi@agr.unand.ac.id)

\begin{abstract}
ABSTRAK
Penelitian ini bertujuan untuk mempelajari serangga predator dan parasitoid pada daerah endemik serangan ulat api. Penelitian dilaksanakan pada Kecamatan Timpeh yang terdiri dari lima nagari yaitu Panyubarangan, Ranah Palabi, Tabek, Timpeh, dan Taratak Tinggi. Penelitian ini berbentuk survei dengan penentuan titik sampel menggunakan metode Purposive Random Sampling. Koleksi serangga contoh menggunakan nampan kuning, jaring ayun, dan koleksi langsung. Identifikasi serangga sampel dilakukan sampai tingkat famili. Data dianalisis dengan menggunakan Indeks Keanekaragaman Shannon-Wienner, Kemerataan Simpson'n, dan Indeks Nilai Penting (INP). Pada penelitian ini ditemukan sebanyak 11 famili serangga predator dan 2 famili parasitoid. Berdasarkan lokasi penelitian kelimpahan serangga predator dan parasitoid paling banyak terdapat di Nagari Panyubarangan yakni 95 individu dan Ranah Palabi yakni 92 individu. Keanekaragaman serangga predator pada perkebunan kelapa sawit endemik serangan ulat api tergolong sedang sedangkan parasitoid tergolong rendah. Famili serangga predator yang ditemukan pada penelitian ini antara lain Cleridae, Mordellidae, Forficulidae, Reduviidae, Pompilidae, Spechidae, Vespidae, Libellulidae, Gryllidae, Mantidae. Dari beberapa famili tersebut predator yang memiliki nilai INP yang tertinggi adalah Reduviidae.
\end{abstract}

Kata Kunci: hama, musuh alami, keanekaragaman, kelapa sawit, ulat api

\section{ABSTRACT}

This research aims to study insects predatory and parasitoids in endemic areas of nettle caterpillar attacks. The research was conducted in Timpeh sub-district which consisted of five villages, namely Panyubarangan, Ranah Palabi, Tabek, Timpeh, and Taratak Tinggi. This research was in the form of a survey by determining sample points using a purposive random sampling method. Collection of sample insects using yellow trays, swing nets, and direct collection. The identification of the sample insects was carried out to the family level. Data were analyzed using the shannon-wienner diversity index, Simpson's Evenness, and Importance Value Index (INP). In this study, 11 predatory insect families and two parasitoid families were found. Based on the research location, the abundance of insects predatory and parasitoids was mostly found in Nagari Panyubarangan was 95 individuals and Ranah Palabi was 92 individuals. Diversity of predatory insects in oil palm plantations was endemic when the nettle caterpillar attacks were classified as moderate whereas parasitoids were relatively low. Predatory insect families found in this study include Cleridae, Mordellidae, Forficulidae, Reduviidae, Pompilidae, Spechidae, Vespidae, Libellulidae, Gryllidae, Mantidae. Of these families, the predator with the highest INP value was Reduviidae

Keywords: diversity, nettle caterpillar, natural enemies, oil palm, pest

\section{PENDAHULUAN}

Serangan hama pada tanaman kelapa sawit dapat menghambat pertumbuhan kelapa sawit serta menyebabkan penurunan produksi sampai $70 \%$ dan di waktu yang bersamaan dengan serangan penyakit maka kerusakan bisa mencapai 100\%. Kerugian lain yang ditimbulkan adalah bertambahnya biaya yang harus dikeluarkan untuk pengendalian dan memulihkan kondisi 
tanaman. Hama dapat menyerang kelapa sawit pada fase pembibitan sampai budidaya di lapangan. Sebagian besar hama yang menyerang kelapa sawit berasal dari kelompok serangga terutama dari ordo Lepidoptera. Hama yang menyerang kelapa sawit antara lain ulat api [Thosea asigna (Lepidoptera: Limacodidae), Setora nitens (Lepidoptera: Limacodidae), Darna trima (Lepidoptera: Limacodidae), dan Thosea bisura (Lepidoptera: Limacodidae)], ulat kantung [Metisa plana (Lepidoptera: Psychidae) dan Mahasena corbeti (Lepidoptera: Psychidae), Pteroma pendula Joannis (Lepidoptera: Psychidae)], kumbang tanduk [Oryctes rhinoceros (Coleoptera: Scarabaeidae)], dan belalang [Valanga nigricornis (Orthoptera: Acrididae)] (Febriani et al., 2020; Priwiratama et al., 2019; Kamarudin \& Wahid, 2010). Serangga hama tersebut menyerang hampir semua bagian tanaman kelapa sawit mulai dari akar, batang, tandan buah, dan daun. Dari beberapa bagian yang diserang tersebut, kerusakan pada daun lebih banyak berpengaruh terhadap produksi karena mengganggu proses fotosistensi (Ajambang et al., 2015). Gangguan proses fisiologi tersebut akan mengurangi ketersedian asimilat untuk pembentukan tandan buah segar (TBS). Selain itu seranggan hama pada daun juga mengakibatkan tanaman kelapa sawit stress, pada kondisi tersebut bunga jantan lebih banyak terbentuk dibandingkan bunga betina.

Hama yang menyerang kelapa sawit menyebabkan tingkat kerusakan yang bervariasi. Dari beberapa hama yang dilaporkan menyerang kelapa sawit tercatat ulat api menjadi hama dengan tingkat kerusakan yang tinggi. Menurut Direktorat Perlindungan Perkebunan diketahui ulat api menyerang kelapa sawit secara nasional seluas 14.993,28 ha selama tahun 2014, sedangkan luas serangan ulat api di Provinsi Sumatera Barat seluas 1.139 ha. Kerusakan yang disebabkan oleh ulat api tersebar hampir pada semua sentra produksi kelapa sawit di Indonesia. Spesies ulat api yang dilaporkan menyerang kelapa sawit sebanyak 12 spesies, yaitu $S$. asigna, $S$. nitens, D. trima, Susica malayana, Thosea vetusta, Thosea monoloncha, Bithosea bisura, Darna diducta, Birthamula chara, Darna catenanus, Darna bradleyi, Parasa lepida (Basri et al., 1995). Dari 12 spesies tersebut dilaporkan Febriani et al. (2020) bahwa jenis ulat api yang paling merusak di Indonesia akhir-akhir ini adalah S. asigna, S. nitens dan D. trima.

Berbagai rakitan teknologi pengendalian sudah diaplikasikan untuk mengendalikan ulat api di Indonesia. Pengendalian secara kimiawi menggunakan pestisida masih menjadi pilihan utama oleh pelaku usaha tani kelapa sawit. Bahan aktif insektisida yang banyak digunakan antara 
lain monocrotophos, dicrotophos, phosmamidon, leptophos, quinalphos, endosulphan, aminocarb, dan achepate. Baru-baru ini ditemukan bahan aktif insektisida baru dari golongan benzenadikarboksamida yang bernama flubendiamida. Insektisida ini dilaporkan memiliki selektivitas dan toksisitas yang tinggi terhadap serangga dari kelompok Lepidoptera (Tohnishi et al., 2010). Di Indonesia insektisida tersebut sudah diuji Priwiratama et al. (2018) dan diketahui efektif untuk mengendalikan S. asigna, $M$. plana, dan T. rufivena. Pengendalian dalam jangka pendek menggunakan pestisida memberikan hasil yang optimal. Dilaporkan dibeberapa daerah di Indonesia pengendalian dengan mengunakan insektisida dalam waktu singkat dapat menekan populasi ulat api di bawah ambang ekonomi. Sebaliknya dibeberapa daerah yang sudah lama menggunakan pestisida dilaporkan efektifitas pestisida sudah mulai berkurang. Hal ini diduga disebabkan oleh muncul spesies ulat api yang resisten. Penggunaan pestisida secara tidak bijaksana bukan hanya menyebabkan resistensi hama akan tetapi juga mengakibtakan terjadinya resurjensi, peledakan hama sekunder serta keracunan terhadap aplikator. Untuk mengurangi efek negatif dari penggunaan pestisida, dapat dilakukan dengan mengaplikasikan pengendalian hayati.
Prinsip pengendalian hayati adalah pengelolaan hama dengan memanfaatkan musuh alaminya seperti predator, parasitoid, dan entomopatogen. Musuh alami ulat api dari kelompok predator sebagian besar berasal dari serangga dan laba-laba. Serangga predator yang dilaporkan pada perkebunan kelapa sawit berasal dari Ordo Hemiptera, dan Dermaptera, dan Hymenoptera. Dari ordo Hymenoptera dilaporkan Romarta et al. (2020) bahwa pada perkebunan kelapa sawit rakyat di Kecamatan Timpeh, Kabupaten Dharmasraya ditemukan sebanyak 29 spesies semut yang berpotensi sebagai musuh alami. Berikutnya dilaporkan Diratika et al. (2020) dilaporkan predator dari Ordo Hemiptera bahwa terdapat enam spesies kepik predator pada ekosistem perkebunan kelapa sawit rakyat salah satunya adalah E. furcelata. Jumlah tersebut lebih sedikit dibandingkan yang dilaporkan Rizali et al. (2018) dimana pada perkebuna kelapa sawit di Pangkalan Bun Kalimantan Tengah ditemukan 19 spesies Hemiptera predator dan spesies yang mendominasi adalah Sycanus sp., Eocanthecona sp. dan. Selain itu juga terdapat predator dari ordo Celeoptera khususnya famili Coccinellidae, seperti yang dilaporkan Muhammad et al. (2019) bahwa terdapat 7 spesies pada perkebunan kelapa sawit, kakao dan karet. 
Berikutnya musuh alami ulat api yang potensial terdapat pada ekosistem perkebunan kelapa sawit adalah parasitoid. Parasitoid merupakan serangga yang pada stadia larva berperan sebagai parasit terhadap serangga lain, sedangkan pada fase imago serangga hidup dengan memakan nektar bunga di alam. Parasitoid yang digunakan sebagai agens pengendali hayati umumnya berasal dari ordo Hymenoptera (84.4\%) dan Diptera (1.4\%). Dilaporkan Rizali et al. (2019) bahwa terdapat 237 spesies, 2669 individu yang termasuk ke dalam 15 famili parasitoid pada perkebunan kelapa sawit. Hal yang berbeda dilaporkan Tawakkal et al. (2019) dimana terdapat perbedaan jumlah spesies parasitoid berdasarkan bentuk perkekebunan kelapa sawit, pada kelapa sawit rakyat dilaporkan terdapat 26 morfospesies sedangkan pada perkebunan kelapa sawit besar ditemukan 8 morfospesies. Pada perkebunan kelapa sawit di India, dilaporkan Potineni dan Saravanan (2013) bahwa terdapat tiga parasitoid hama pemakan daun kelapa sawit yakni Goriphous bunoh, Brachymeria spp. dan Dolichogenidea metesae.

Pemanfaatan serangga predator dan parasitoid untuk pengendalian ulat api perkebunan kelapa sawit yang terdapat di Sumatera Barat masih sedikit dilaporkan, termasuk di Kabupaten Dharmasraya yang merupakan salah satu sentral produksi kelapa sawit di Sumbar. Pada tahun 2017 terjadi ledakan hama ulat api di Kabupaten Dharmasraya, tepatnya di Kecamatan Timpeh. Dilaporkan Febriani et al. (2020) bahwa luas serangan hama ulat api di kecamatan tersebut mencapai 60 ha. Serangan tersebut tergolong berat karena hampir sebagian besar daun kelapa sawit yang terserang hanya menyisakan lidi pada pelepah daun. Bahkan serangan tersebut berlanjut sampai pertengahan tahun 2017. Upaya pengendalian yang dilakukan petani dan instansi terkait tidak memberikan hasil yang optimal. Hal ini disebabkan terbatasnya informasi tentang ulat api dan musuh alami hama tersebut.

Pengamatan yang dilakukan pada akhir bulan Agustus sudah memperlihatkan penurunan tingkat serangan. Hal ini tidak terlepas dari instensifnya pengendalian menggunakan pestisida dengan dosis yang tinggi, disertai frekuensi penyemprotan yang sering. Berdasarkan survei yang dilakukan di lapangan diketahui salah satu penyebab terjadinya ledakkan hama ulat api adalah aktifitas penyemprotan herbisida yang tinggi yang dilakukan petani pada tanaman vegetasi bawah kelapa sawit. Kondisi ini diduga menyebabkan matinya musuh alami yang terdapat pada ekosistem kelapa sawit. Hal ini tidak terlepas dari kurangnya pengetahuan petani tentang serangga-serangga bermanfaat yang terdapat pada ekosistem perkebunan kelapa 
sawit khususnya predator dan parasitoid. Perlu dilakukan penelitian untuk mengeksplorasi musuh alami yang terdapat pada ekosistem perkebunan kelapa sawit terutama pada daerah endemik serangan ulat api. Informasi ini akan menjadi dasar untuk merakit teknologi pengendalian dan mengkonservasi musuh alami.

\section{METODE PENELITIAN}

Penelitian ini dilaksanakan di Nagari Panyubarangan, Ranah Palabi, Tabek, Timpeh, dan Taratak Tinggi Kecamatan Timpeh Kab. Dharmasraya. Penelitian ini berbentuk survei lapangan. Lokasi penelitian ditentukan dengan metode Purposif Random Sampling. Kriteria pemilihan lokasi adalah kecamatan yang terdapat di Kabupaten Dharmasraya dan pernah dilaporkan terdapat serangan ulat api dalam kurun waktu lima tahun terakhir. Berdasarkan kriteria tersebut, ditetapkan lokasi penelitian di Kecamatan Timpeh. Pada Kecamatan yang sudah ditentukan dipilih sebanyak 5 Nagari. Pada masingmasing nagari dipilih sebanyak dua kebun kelapa sawit. Total kebun untuk pengamatan sebanyak 10 kebun. Luas kebun yang digunakan sebagai tempat pengambilan sampel \pm 1 ha. Deskripsi lokasi penelitian disajikan pada Tabel 1 .

Garis transek ditentukan sepanjang 1 $\mathrm{km}$, pada garis tersebut ditentukan sebanyak 10 titik sampel, dengan jarak antar titik sampel $100 \mathrm{~m}$ (Diratika et al., 2020). Garis transek dibuat sebannyak 2 buah yakni untuk penentuan titik peletakan nampan kuning dan jaring ayun. Jarak antar garis transek yakni $20 \mathrm{~m}$. Penentuan titik awal garis transek pada sisi kebun yang terpanjang agar tercapai panjang garis $1 \mathrm{~km}$. Pada kebun kelapa sawit yang sudah ditentukan dilakukan penentuan tanaman sampel secara sistematis pada baris tanaman. Pada baris pertama dipilih tanaman ke 2 sebagai tanaman sampel, pada baris ke dua dipilih tanaman ke 4 sebagai tanaman sampel. Pola penentuan tersebut dilakukan sampai baris terakhir pada satu kebun.

Pengambilan serangga contoh dilakukan dengan tiga cara, yaitu koleksi seranga secara langsung, jaring ayun, dan nampan kuning (Romarta et al., 2020; Diratika et al., 2020: Safitri et al., 2020). Metode koleksi langsung yaitu metode yang digunakan untuk mengambil sampel serangga stadia imago yang memungkinkan diambil langsung dengan tangan menggunakan bantuan sarung tangan dan pinset pada tanaman sampel. Pada perkebunan kelapa sawit yang dilakukan pengamatan dimulai pada pagi hari pukul 08.00 - 10.00 WIB dan sore hari jam 15.00 - 17.00 WIB. Perangkap ini terbuat dari bahan ringan dan kuat seperti kain kasa, mudah diayunkan. Cara penggunaannya dengan melakukan ayunan dari kanan ke 
Tabel 1. Deskripsi lokasi penelitian

\begin{tabular}{|c|c|c|c|c|}
\hline Nagari & Koordinat & $\begin{array}{c}\text { Ketinggian } \\
\text { Tempat } \\
(\mathrm{m} \mathrm{dpl})\end{array}$ & Kegiatan Agronomis & $\begin{array}{c}\text { Faktor } \\
\text { Lingkungan }\end{array}$ \\
\hline Ranah Palabi & $\begin{array}{l}\text { LS: } 00^{\circ} 65^{\prime} 59^{\prime \prime} \\
\text { BT: } 101^{\circ} 36^{\prime} 31,0^{\prime}\end{array}$ & 115 & $\begin{array}{l}\text { Umur tanaman } 6 \text { tahun. } \\
\text { Jarak tanam 9x } 9 \text { meter. } \\
\text { Pengendaliah OPT } 3 \text { bulan } \\
\text { sekali. } \\
\text { Varietas yang di } \\
\text { Budidayakan Simalungun. }\end{array}$ & $\begin{array}{l}\text { SH: } 30^{\circ} \mathrm{C} \\
\text { RH: } 70 \% \\
\text { IC: } 1306\end{array}$ \\
\hline Taratak Tinggi & $\begin{array}{l}\text { LS: } 00^{\circ} 97^{\prime} 21^{\prime \prime} \\
\text { BT: } 101^{\circ} 69^{\prime} 59,9^{\prime}\end{array}$ & 95 & $\begin{array}{l}\text { Umur tanaman } 8 \text { tahun. } \\
\text { Jarak tanam } 9 \text { x } 9 \text { meter. } \\
\text { Pengendalian ketika } \\
\text { terserang. } \\
\text { Varietas yang di } \\
\text { Budidayakan Simalungun. }\end{array}$ & $\begin{array}{l}\text { SH: } 27^{\circ} \mathrm{C} \\
\text { RH: } 69 \% \\
\text { IC: } 1196\end{array}$ \\
\hline Timpeh & $\begin{array}{l}\text { LS: } 00^{\circ} 95^{\prime} 90,6^{\prime \prime} \\
\text { BT: } 101^{\circ} 65^{\prime} 49,4^{\prime}\end{array}$ & 100 & $\begin{array}{l}\text { Umur Tanaman } 7 \text { Tahun. } \\
\text { Jarak tanam } 9 \text { x } 9 \text { meter. } \\
\text { Pengendalian dilakukan } \\
\text { ketika terserang. } \\
\text { Varietas yang di } \\
\text { Budidayakan Dumpi. }\end{array}$ & $\begin{array}{l}\text { SH: } 29^{\circ} \mathrm{C} \\
\text { RH: } 76 \% \\
\text { IC: } 1366\end{array}$ \\
\hline Tabek & $\begin{array}{l}\text { LS: } 00^{\circ} 96^{\prime} 14,2^{\prime \prime} \\
\text { BT:101 } 65^{\prime} 90,5^{\prime}\end{array}$ & 107 & $\begin{array}{l}\text { Umur tanaman } 6 \text { tahun. } \\
\text { Jarak tanam } 9 \text { x } 9 \text { meter. } \\
\text { Pengendalian } \\
\text { ketikaterserang. } \\
\text { Varietas yang di } \\
\text { Budidayakan Dumpi. }\end{array}$ & $\begin{array}{l}\mathrm{SH}: 30{ }^{\circ} \mathrm{C} \\
\mathrm{RH}: 69 \% \\
\mathrm{IC}: 1240\end{array}$ \\
\hline Panyubarangan & $\begin{array}{l}\text { LS: } 00^{\circ} 95^{\prime} 87,6^{\prime \prime} \\
\text { BT: } 101^{\circ} 66^{\prime} 64,4^{\prime \prime}\end{array}$ & 106 & $\begin{array}{l}\text { Umur tanaman } 8 \text { tahun. } \\
\text { Jarak tanam } 9 \text { × } 9 \text { meter. } \\
\text { Pengendalian OPT } 3 \text { bulan } \\
\text { sekali. } \\
\text { Varietas yang dibudidayakan } \\
\text { Simalungun. }\end{array}$ & $\begin{array}{l}\mathrm{SH}: 30^{\circ} \mathrm{C} \\
\text { RH: } 72 \% \\
\text { IC: } 1400\end{array}$ \\
\hline
\end{tabular}

Keterangan: $\mathrm{SH}=\mathrm{Suhu}, \mathrm{RH}=$ Kelembaban, $\mathrm{IC}=$ Intensitas Cahaya.

kiri sepanjang $100 \mathrm{~m}$, kemudian serangga yang tertangkap dimasukkan ke botol koleksi. Selanjutnya dilakukan kembali sepanjang $100 \mathrm{~m}$ dan serangga yang tertangkap dimasukkan ke botol koleksi. Begitu seterusnya sampai sejauh $1 \mathrm{~km}$. Pengumpulan serangga dengan jaring ayun dilakukan sebanyak 3 kali dengan interval waktu satu bulan. Penangkapan serangga hama menggunakan yellow pan trap yaitu berupa wadah bulat berwarna kuning yang berisi deterjen. Yellow pan trap dipasang pukul 08.00 WIB kemudian dilakukan pengamatan dan pengambilan sampel yang terjebak pada pukul 16.00 WIB. Setiap petak sampel diletakan sebanyak 10 yellow pan trap pada garis transek yang sudah ditentukan. Pengumpulan serangga dengan yellow pan trap dilakukan sebanyak 2 kali dengan interval satu bulan. 
Identifikasi sampel dilakukan sampai tingkat famili dengan mengacu pada buku kunci identifikasi Weirauch et al. (2014), Borror et al. (1992), dan Goulet and Huber (1994). Analisis data dilakukan sebagai berikut.

\section{Indeks Keanekaragaman}

Keanekaragaman serangga predator dan parasitoid diukur dengan menggunakan indeks keanekaragaman Shannon-Wienner. Indeks Shannon-Wienner tersebut adalah sebagai berikut.

$$
H^{\prime}=\sum_{i=1}^{S S} p i(\operatorname{loge} . p i), \mathrm{pi}=\mathrm{n} / \mathrm{N}
$$

Keterangan :
H' : Indeks keanekaragaman Shannon- Wienner

$\mathrm{Pi}$ : proporsi individu spesies ke i pada komunitas

$\mathrm{n}$ : kelimpahan individu spesies ke $\mathrm{i}$

$\mathrm{N}$ : Jumlah total individu.

2. Indeks Kemerataan Spesies Indeks kemerataan spesies bertujuan untuk mengukur kelimpahan individu spesies pada suatu komunitas pada suatu tempat dan waktu tertentu (Efendi et al., 2017). Kemerataan spesies dihitung menggunakan indeks kemerataan Simpson'n sebagai berikut :

$$
E=\frac{H^{\prime}}{\mathrm{H}_{\max }}
$$

Keterangan :

E : Indeks kemerataan (kisaran 0-1)

H' : Indeks keanekaragaman spesies yang diamati

$\mathrm{H}_{\max }$ : Keanekaragaman spesies maksimum $=\log _{2} \mathrm{~S}$
$\mathrm{S}$ : Jumlah spesies dalam unit pengamatan.

\section{Indeks Nilai Penting}

Indeks Nilai penting (importance value index) bertujuan untuk mengetahui dominansi suatu spesies dalam komunitas tertentu (Yaherwandi et al., 2019). Indeks nilai penting (INP) berkisar antara 0-3. Indeks nilai penting dihitung menggunakan persamaan sebagai berikut:

$$
\mathrm{INP}=\mathrm{RDi}+\mathrm{RF} \mathrm{i}
$$

a. Kepadatan (Di) dengan rumus:

$$
\mathrm{Di}=\mathrm{ni} / \mathrm{A}
$$

Keterangan:

Di : Kepadatan untuk spesies i

ni : Jumlah total individu untuk spesies i

A : Luas total habitat yang disampling

b. Kepadatan Relatif(RDi) dengan rumus: $\mathrm{RDi}=\mathrm{ni} / \sum \mathrm{n}$ atau $\mathrm{RDi}=\mathrm{Di} / \mathrm{TD}=\mathrm{Di} / \sum \mathrm{D}$

Keterangan :

RDi : Kepadatan relatif spesies i

ni : Jumlah total individu untuk spesies i

$\sum \mathrm{n}:$ Jumlah total individu dri semua spesies

Di : Kepadatan spesies

TD : Kepadatan untuk semua spesies

$\sum \mathrm{D}$ : Jumlah total kepadatan semua spesies

c. Frekuensi (Fi) dengan rumus:

$\mathrm{Fi}=\mathrm{Ji} / \mathrm{K}$

Keterangan:

Fi : Frekuensi spesies i,

Ji : Jumlah sampel dimana spesies i terdapat, 
$\mathrm{K}$ : Jumlah total sampel yang didapat

d. Frekuensi Relatif (RFi) dengan rumus:

$\mathrm{RFi}=\mathrm{Fi} / \sum \mathrm{F}$

Keterangan :

RFi : Frekuensi relatif spesies i,

$\mathrm{Fi}$ : Frekuensi spesies $\mathrm{i}$

$\sum \mathrm{F}$ : Jumlah frekuesi untuk semua spesies

\section{HASIL DAN PEMBAHASAN}

\section{Kelimpahan Serangga Predator dan Parasitoid}

Total individu serangga yang dikoleksi pada setiap lokasi pengambilan sampel sebanyak 411 individu yang terdiri dari 7 ordo dan 13 famili, terdiri dari 11 famili serangga predator dan 2 famili parasitoid (Tabel 2). Berdasarkan data tersebut terlihat kalau musuh alami dari kelompok predator lebih banyak dibandingkan parasitoid pada perkebunan kelapa sawit. Dari hasil identifikasi ditemukan sebanyak 11 famili serangga predator antara lain Carabidae, Cleridae, Mordellidae, Forficulidae, Reduviidae, Pompilidae, Spechidae, Vespidae, Libellulidae, Gryllidae, Mantidae. Parasitoid yang ditemukan pada perkebunan kelapa sawit berjumlah 2 famili yakni Conopidae dan Ichneumonidae. Banyak faktor yang mendukung keberadaan serangga predator pada perkebunan kelapa sawit dibandingkan parasitoid mulai dari kesesuian habitat, faktor fisik, dan ketersediaan mangsa.
Perkebunan kelapa sawit rakyat sebagian besar tidak dikelola secara intensif, begitu juga perkebunan yang digunakan sebagai lokasi penelitian. Salah satu kegiatan agronomis yang jarang dilakukan pada perkebunan kelapa sawit rakyat adalah pengendalian gulma, hal ini mengakibatkan berbagai vegetasi tumbuh dengan cepat dan menutup sebagian besar gawangan antar tanaman. Pada saat pengamatan dilapangan, sebagian serangga predator ditemukan pada gulma-gulma tersebut. Hanya saja gulma yang tumbuh tersebut sebagian besar bukan gulma berbunga, padahal gulma berbunga dapat mendukung keberadaan parasitoid.

Selain itu keberadaan serangga predator di perkebunan kelapa sawit rakyat juga berhubungan dengan sifat predator yang sebagai besar adalah generalis, sehingga predator dapat melangsungkan hidupnya tanpa harus tergantung pada mangsa utama. Serangga predator ini dapat bertahan hidup dengan memakan mangsa alternatif. Serangga predator mempunyai peranan penting pada ekosistem kelapa sawit karena dapat mengendalikan beberapa serangga hama sehingga menjadi salah satu komponen penting dalam menjaga keseimbangan populasi alami di suatu ekosistem.

Diantara 11 famili tersebut, ditemukan 1 predator ulat api yakni dari spesies Sycanus leucomesus (Hemiptera : Reduviidae). Sebelumnya dilaporkan 
Tabel 2. Kelimpahan serangga predator dan parasitoid pada perkebunan kelapa sawit

\begin{tabular}{llccc}
\hline \multicolumn{1}{c}{ Ordo } & \multicolumn{1}{c}{ Famili } & Morfospesies & Individu & Fungsional \\
\hline Coleoptera & Carabidae & 1 & 17 & Predator \\
& Cleridae & 1 & 13 & Predator \\
& Mordellidae & 1 & 19 & Predator \\
Dermaptera & Forficulidae & 1 & 34 & Predator \\
Diptera & Conopidae & 1 & 10 & Parasitoid \\
Hemiptera & Reduviidae & 3 & 119 & Predator \\
Hymenoptera & Ichneumonidae & 1 & 41 & Parasitoid \\
& Pompilidae & 1 & 41 & Predator \\
& Sphecidae & 1 & 2 & Predator \\
& Vespidae & 1 & 30 & Predator \\
Odonata & Libellulidae & 2 & 25 & Predator \\
Orthoptera & Gryllidae & 2 & 34 & Predator \\
& Mantidae & 1 & 26 & Predator \\
\hline
\end{tabular}

Tabel 3. Kelimpahan Serangga Predator dan Parasitoid Berdasarkan Lokasi Penelitian

\begin{tabular}{|c|c|c|c|c|c|}
\hline Ordo/Famili & PY & $\mathrm{RP}$ & TB & TT & $\mathrm{TP}$ \\
\hline \multicolumn{6}{|l|}{ Coleoptera } \\
\hline Carabidae & 10 & 4 & 0 & 3 & 0 \\
\hline Cleridae & 4 & 6 & 3 & 0 & 0 \\
\hline Mordellidae & 6 & 3 & 2 & 0 & 8 \\
\hline \multicolumn{6}{|l|}{ Dermaptera } \\
\hline Forficulidae & 5 & 12 & 5 & 5 & 7 \\
\hline \multicolumn{6}{|l|}{ Diptera } \\
\hline Conopidae & 0 & 1 & 5 & 4 & 0 \\
\hline \multicolumn{6}{|l|}{ Hemiptera } \\
\hline Reduviidae & 29 & 22 & 20 & 22 & 26 \\
\hline \multicolumn{6}{|l|}{ Hymenoptera } \\
\hline Ichneumonidae & 9 & 7 & 8 & 9 & 8 \\
\hline Pompilidae & 9 & 10 & 10 & 5 & 7 \\
\hline Sphecidae & 0 & 1 & 1 & 0 & 0 \\
\hline Vespidae & 8 & 6 & 3 & 6 & 7 \\
\hline \multicolumn{6}{|l|}{ Odonata } \\
\hline Libellulidae & 7 & 8 & 2 & 4 & 4 \\
\hline \multicolumn{6}{|l|}{ Orthoptera } \\
\hline Gryllidae & 8 & 7 & 4 & 9 & 6 \\
\hline Mantidae & 0 & 5 & 8 & 9 & 4 \\
\hline
\end{tabular}

Diratika et al., (2020) bahwa terdapat delapan spesies kepik predator pada perkebunan kelapa sawit rakyat dan tiga spesies diantaranya adalah predator ulat api dan salah satu spesies kepik predator ulat api tersebut adalah Sycanus sp. Berikutnya dari kedua famili parasitoid yang ditemukan yang merupakan parasitoid ulat api adalah 
p-ISSN: 1410-0029; e-ISSN2549-6786

Agrin Vol. 24, No. 1, April 2020

dari spesies Spinaria spinator

(Hymenoptera : Ichneumonidae).

\section{Kelimpahan Serangga Predator dan Parasitoid Berdasarkan Lokasi Penelitian}

Kelimpahan serangga predator dan parasitoid yang ditemukan pada masingmasing lokasi penelitian berbeda. Dimana total kelimpahan yang ditemukan pada masing-masing lokasi yakni di Nagari Panyubarangan sebanyak 95 individu, Ranah Palabi sebanyak 92 individu, Tabek sebanyak 71 individu, Taratak Tinggi sebanyak 76 individu, dan Timpeh sebanyak 77 individu (Tabel 3). Perbedaan kondisi lingkungan (suhu, kelembaban, curah hujan, intensitas cahaya) dan pola budidaya kelapa sawit pada masing-masing lokasi menjadi penyebab berbedanya kelimpahan serangga predator dan parasitoid yang terkoleksi, karena kelimpahan serangga predator dan parasitodi dipengaruhi oleh salah satu kondisi lingkungan (Tabel 1). Secara umum diketahui bahwa kehidupan serangga sangat erat hubungannya dengan keadaan lingkungan disekitar habitatnya seperti suhu, kelembaban, cahaya matahari, vegetasi dan jumlah makanan.

Berdasarkan Tabel 3 terlihat bahwa kelimpahan serangga predator dan parasitoid tertinggi yakni pada Nagari Panyubarangan sebanyak 95 individu yang terdiri dari 10 famili. Topografi kebun kelapa sawit di Nagari Panyubarangan berbukit dengan umur tanaman 8 tahun. Hal tersebut tidak terlepas dari kondisi perkebunan kelapa sawit di Nagari Panyubarangan merupakan endemik serangan ulat api, artinya populasi ulat api sebagai mangsa yang tinggi mengundang beberapa musuh alami pada lokasi tersebut. Dilaporkan Febriani et al. (2020) terdapat dua spesies ulat api yang menyerang pada perkebunan kelapa sawit rakyat di Nagari Panyubarangan yakni S. asigna dan D.trima. Selain itu pada perkebunan kelapa sawit rakyat di Nagari Panyubarangan banyak tumbuhan liar berbunga. Dilaporkan Rizali et al. (2018) keberadaan serangga predator khususnya Sycanus sp. dipengaruhi oleh vegetasi berbunga yang ada di lahan kelapa sawit. Selain itu aplikasi insektisida di lokasi penelitian jarang dilakukan oleh petani, begitu juga dengan penggunaan herbisida untuk mengendalikan gulma juga dilakukan secara selektif yakni dengan metode piringan. Artinya tidak semua gulma yang terdapat perkebunan kelapa sawit disemprot dengan herbisida, sehingga beberapa gulma yang tidak terdapat di dalam piringan masih tersedia sebagai habitat alternatif. Kelimpahan serangga predator dan parasitoid paling sedikit yakni pada Nagari Tabek sebanyak 71 individu yang terdiri dari 12 famili. Tabek adalah nagari yang paling parah terkena serangan ulat api 
dibandingkan beberapa nagari lain di Kecamatan Timpeh. Kondisi ini yang menyebabkan dilakukan pengendalian secara besar-besaran dengan menggunakan insektisida berbahan aktif sipermetrin dan lamda- sihalotrin. Padahal dilaporkan Priwiratama et al. (2018) bahwa insektisida tersebut bersifat spektrum luas sehingga berdampak negatif terhadap serangga bermanfaat seperti parasitoid, predator, dan kumbang penyerbuk Elaeidobius kamerunicus.

\section{Indeks Keanekaragaman dan Kemerataan Serangga Predator dan Parasitoid}

Keanekaragaman dan kemerataan serangga predator jauh lebih tinggi dibandingkan serangga parasitoid. Indeks keanekaragaman ( $\left.\mathrm{H}^{\prime}\right)$ serangga predator dan parasitoid pada perkebunan kelapa sawit rakyat yakni 2,09 dan 0,50 (Tabel 4). Nilai indeks keanekaragaman dipengaruhi kemerataan jenis dalam suatu komunitas. Nilai kemerataan jenis akan cenderung rendah bila komunitas tersebut didominasi satu spesies saja. Tiga kriteria nilai indeks keanekaragaman yaitu, bila $\mathrm{H}^{\prime}<1,5$ berarti keanekaragaman tergolong rendah, bila $\mathrm{H}^{\prime}$ $=1,5-3,5$ berarti keanekaragaman tergolong sedang, bila $\mathrm{H}^{\prime}>3,5$ berarti keanekaragaman tergolong tinggi. Indeks keanekaragaman serangga predator pada perkebunan kelapa sawit termasuk kedalam kategori sedang yakni 1,5-3,5. Indeks keanekaragaman sedang menunjukkan bahwa suatu komunitas yang ada pada suatu ekosistem di susun oleh individu dengan kelimpahan individu yang hampir sama bahkan hanya beberapa spesies saja yang dominan sehingga keanekaragaman jenisnya sedang. Sedangkan indeks keanekaragaman serangga parasitoid tergolong rendah yakni $<1,5$. Ini memandakan bahwa keberadaan serangga parasitoid pada suatu kawasan ini sangat rendah (Efendi et al., 2016).

Nilai indeks kemerataan (E') dapat menggambarkan kestabilan suatu komunitas. Tiga kriteria komunitas lingkungan berdasarkan nilai kemerataan, yakni bila E' <0,50 maka komunitas berada pada kondisi tertekan. Bila E’ 0,50 - 0,75 maka komunitas berada dalam kondisi labil sedangkan E'>0,75 - 1,00 maka komunitas berada dalam konsidi stabil. Nilai indeks kemerataan serangga predator berada pada kondisi stabil yakni 0,77 sedangkan nilai indeks kemerataan serangga parasitoid berada pada kondisi labil yakni 0,71. Semakin kecil nilai E' atau mendekati nol, maka semakin tidak merata penyebaran organisme dalam komunitas tersebut yang didominasi oleh jenis tertentu dan sebaliknya semakin besar nilai E' atau mendekati satu, maka organisme dalam komunitas akan menyebar secara merata. Serangga predator memiliki nilai indeks kemerataan yang stabil. Keadaan ini 
Tabel 4. Indeks Kemerataan dan Indeks Keanekaragaman Serangga Predator dan Parasitoid

\begin{tabular}{lcc}
\hline \multirow{2}{*}{ Parameter } & \multicolumn{2}{c}{ Fungsional } \\
\cline { 2 - 3 } & Predator & Parasitoid \\
\hline Jumlah Morfospesies & 15 & 2 \\
Jumlah Individu (N) & 360 & 51 \\
Indeks Keanekaragaman $\left(\mathrm{H}^{\prime}\right)$ & 2,09 & 0,50 \\
Indeks Kemerataan (E) & 0,77 & 0,71 \\
\hline
\end{tabular}

Tabel 5. Indeks Nilai Penting (INP) Serangga Predator dan Parasitoid

\begin{tabular}{llll}
\hline \multicolumn{1}{c}{ Ordo } & \multicolumn{1}{c}{ Family } & INP & Fungsional \\
\hline Coleoptera & Carabidae & 0.11 & Predator \\
& Cleridae & 0.09 & Predator \\
& Mordellidae & 0.13 & Predator \\
Dermaptera & Forficulidae & 0.17 & Predator \\
Diptera & Conopidae & 0.09 & Parasitoid \\
Hemiptera & Reduviidae & 0.38 & Predator \\
Hymenoptera & Ichneumonidae & 0.19 & Parasitoid \\
& Pompilidae & 0.19 & Predator \\
& Sphecidae & 0.02 & Predator \\
& Vespidae & 0.15 & Predator \\
Odonata & Libellulidae & 0.15 & Predator \\
Orthoptera & Gryllidae & 0.17 & Predator \\
& Mantidae & 0.15 & Predator \\
\hline
\end{tabular}

menandakan bahwa setiap jenis serangga predator pada ekosistem tersebut memiliki tingkat penyebaran jenis yang merata. Tidak ada jenis yang dominan dalam area, sehingga tiap individu memiliki kesempatan yang sama dalam suatu komunitas. Semakin tinggi nilai indeks kemerataan, maka semakin sama kesempatan dari setiap jenis serangga dalam komunitas tersebut (Romarta et al., 2020).

\section{Indeks Nilai Penting (INP) Serangga Predator dan Parasitoid}

Nilai Indeks nilai penting (INP) serangga predator dan parasitoid pada penelitian ini yakni berkisar antara 0,02 0,38 . INP serangga predator yang tertinggi terdapat pada famili Reduviidae yakni 0,38, sedangkan indeks nilai penting serangga parasitoid yang paling tinggi terdapat pada famili Ichneumonidae yakni 0,19. Ini menandakan bahwa famili Ichneumonidae sangat mendominasi serangga parasitoid lainnya dalam satu kawasan tersebut (Tabel 5). Famili Reduviidae memiliki nilai INP paling tinggi, Kepik ini merupakan serangga yang paling dominan ditemukan dibandingkan serangga predator dan parasitoid lainnya. Pada penelitian ini ditemukan sebanyak 3 spesies kepik predator. Menurut Diratika et al. (2020) bahwa di Indonesia salah satu spesies Reduviidae yaitu Sycanus sp. adalah kepik 
yang berwarna hitam dan merah dengan abdominal strip yang berwarna putih, kepik ini merupakan predator larva S. asigna. di pertanaman kelapa sawit. Sycanus $s p$. (Hemiptera: Reduviidae) merupakan predator yang mampu menekan populasi ulat api dan juga ulat bulu. Spesies ini memiliki potensi sebagai agen hayati karena mempuyai kisaran mangsa yang luas terutama ordo Lepidoptera. Selain itu dilaporkan Rizali et al. (2018) bahwa semakin banyak vegetasi bawah yang terdapat di dalam suatu habitat, maka semakin banyak pula sumber nutrisi dan inang alternatif yang dapat digunakan oleh musuh alami untuk dapat melangsungkan hidup.

\section{KESIMPULAN}

Pada daerah endemik serangan ulat api di Kabupaten Dharmasraya yakni di Kecamatan Timpeh ini ditemukan 11 famili serangga predator yang terdiri dari Famili Carabidae, Cleridae, Mordellidae, Forficulidae, Reduviidae, Pompilidae, Spechidae, Vespidae, Libellulidae, Gryllidae, Mantidae. Serangga parasitoid terdiri dari 2 famili yakni Conopidae dan Ichneumonidae. Kanekaragaman serangga predator pada daerah ini mempunyai nilai indeks keanekaragaman yang tergolong sedang yakni 2,09 dan indeks keanekaragaman serangga parasitoid tergolong rendah yakni 0,50 . Serangga yang paling umum ditemukan yakni famili Reduviidae dengan nilai INP 0,38 kepik ini merupakan predator di pertanaman kelapa sawit.

\section{DAFTAR PUSTAKA}

Ajambang, W., S.W. Ardie, H. Volkaert, M. Galdima, and S. Sudarsono. 2015. Huge carbohydrate assimilates delay response to complete defoliation stress in oil palm (Elaeis guineensis Jacq.). Emirates Journal of Food and Agriculture, 27(1): 127-138. https: //doi.org/10.9755/ejfa.v27i1.18734

Basri, Norman, and Hamdan. 1995. Natural enemies of the bagworm, Metisa plana Walker (Lepidoptera: Psychidae) and their impact on host population regulation. Crop Protection, 14(8): 637-645.

Bertolaccini, I., E. Núñez-Pérez, and E.J. Tizado. 2008. Effect of wild flowers on oviposition of Hippodamia variegata (Coleoptera: Coccinellidae) in the laboratory. Journal of Economic Entomology, 101(6): 1792-1797. https://doi.org /10.1603/0022-0493-101.6.1792

Borror, D.J., C.A. Triplehorn, dan N.F. Johnson. 1992. Pengenalan Pelajaran Serangga Edisi Keenam. Gadjah Mada University Press, Yogyakarta.

Diratika, M., Yaherwandi, dan S. Efendi. 2020. Kelimpahan kepik predator (Hemiptera: Reduviidae) ulat api pada perkebunan kelapa sawit rakyat. Penelitian Pertanian Terapan, 20(1): $1-10$.

Efendi, S., Yaherwandi, dan N. Nelly, 2017. Analisis keanekaragaman coccinellidae predator dan kutu daun (Aphididae spp) pada ekosistem pertanaman cabai di Sumatera Barat. Jurnal Bibit, 1(2): 67-80. https:// doi.org/10.22216/jbbt.vli2.1697. 
Febriani, Yusniwati, dan S. Efendi, 2020. Inventarisasi hama kelapa sawit (Elaeis guineensis Jacq.) pada daerah endemik serangan di Kabupaten Dharmasraya. Agrifor, 19(1): 1-10.

Goulet, H., and J.T. Huber, 1994. Hymenoptera of the world: an identification guide to families. American Entomologist, 40 (2): 115116. https://doi.org/10.1093/ae/40.2. 115

Kamarudin, N., and M.B. Wahid, 2010. Interactions of the bagworm, Pteroma pendula (Lepidoptera: Psychidae), and its natural enemies in an oil palm plantation in Perak. Journal of Oil Palm Resear., 22: 758-764.

Muhammad, A., Y. Yaherwandi, , A. Noferta, dan S. Efendi, 2019. Keanekaragaman Coccinellidae Predator Pada Beberapa Ekosistem Perkebunan di Kabupaten Dharmasrata. Jurnal Tadris Biologi, 10(2): 157-168.

Potineni, K., and L. Saravanan. 2013. Natural enemies of oil palm defoliators and their impact on pest population. Pest Management in Horticultural Ecosystems 19(2): 179184.

Priwiratama, H., T. Ahmad, P. Rozziansha, A.E. Prasetyo, and A. Susanto. 2019. Effect of bagworm Pteroma pendula Joannis attack on the decrease in oil palm productivity. Jurnal Hama dan Penyakit Tumbuhan Tropika, 19(2): 101-108.

Priwiratama, H., T.A.P. Rozziansha, dan A. E.Prasetyo. 2018. Efektivitas flubendiamida dalam pengendalian ulat api Setothosea Asigna van Eecke, ulat kantung Metisa Plana walker, dan penggerek tandan Tirathaba Rufivena Walker serta pengaruhnya terhadap aktivitas kumbang penyerbuk Elaeidobius kamerunicus faust. Jurnal Penelitian Kelapa Sawit, 26(3): 129-140.
Rizali, A., T. Himawan, I. Fitriani, B. T. Rahardjo, dan S. Karindah. 2018. Effect of natural habitat on diversity of Hemipteran predator in oil palm plantation. Jurnal Hama dan Penyakit Tumbuhan Tropika, 18 (1): 903-907.

Rizali, A., S. Karindah, T. Himawan, M. Luthfie, dan T. Meiadi, 2019. Parasitoid wasp communities on oil palm plantation: Effects of natural habitat existence are obscured by lepidopteran abundance. Journal of Asia-Pacific Entomology, 22(3): 903-907. https://doi.org/10.1016/ j.aspen.2019.07.012.

Romarta, R., Y. Yaherwandi, dan S. Efendi, 2020. Keanekaragaman Semut Musuh Alami (Hymenoptera: Formicidae ) pada Perkebunan Kelapa Sawit Rakyat di Kecamatan Timpeh Kabupaten Dharmasraya. Agrikultura, 31(1): 42-51.

Safitri, D., Y. Yaherwandi, dan S. Efendi, 2020. Keanekaragaman serangga herbivora pada ekosistem perkebunan kelapa sawit rakyat di Kecamatan Sitiung Kabupaten Dharmasraya. Menara Ilmu, 14(01): 19-28.

Tawakkal, M.I., D. Buchori, A. Rizali, A. Sari, dan Pudjianto. 2019. Parasitoid diversity and host-parasitoid interaction in oil palm plantations. Jurnal Perlindungan Tanaman Indonesia, 23(1): 39-46. https: //doi.org/10.22146/jpti.31232

Tohnishi, M., T. Nishimatsu, K. Motoba, T. Hirooka, and S. Akira, 2010. Society Awards 2010 Development of a Novel Insecticide, Flubendiamide. Journal of Pesticide Science 35(4): 490-491. https://doi.org/10.1584 /jpestics.J10-06

Weirauch, C., J. Bérenger, L. Berniker, , D. Forero, M. Forthman, S. Frankenberg, and J. Zhang, 2014. An Illustrated identification key to assass in bug subfamilies and tribes (Hemiptera: Reduviidae). Canadian 
Journal of Arthropod Identification 26(26): 1-115. https://doi.org/10.37 52/cjai.2014.26

Yaherwandi, H. Herwina, M. Busniah, S. Efendi, and D.A. Hasan, 2019. The Influence of forest ecosystems to ant community on smallholder oil palm plantations at Dharmasraya Regency, West Sumatera Indonesia. IOP Conference Series: Earth and Environmental Science, 347(1). https: //doi.org/10.1088/1755-1315/347/1/ 012104 . 